\title{
STRESS DAN CARA MENGURANGINYA
}

\author{
Sukadiyanto \\ (FIK Universitas Negeri Yogykarta, Hp. 085868592414; \\ Email: sukadiyanto_fik@yahoo.com)
}

\begin{abstract}
Stress and How to Reduce It. Everyone experiences stress or tension but it will vary from person to person. The difference lies in its intensity and the way to respond to its causes. Some ways to reduce stress include, among others, consuming healthy and nutritious foods, maintaining physical fitness, doing breath exercises, doing relaxation exercises, doing fun activities, taking a vacation, establishing harmonious relationship, avoiding bad habits, planning daily routines, keeping plants and animals, sparing time for oneself or families, and avoiding loneliness. A stress-reducing program can be successful if it is seriously carried out with discipline.
\end{abstract}

Keywords: stress, a stress-reducing program

\section{PENDAHULUAN}

Pada umumnya, setiap orang pernah mengalami perasaan tertekan atau mengalami ketegangan yang dalam bahasa populernya dikenal dengan istilah stress. Sebab stress merupakan bagian dari kehidupan manusia, artinya bahwa manusia tidak akan pernah luput dari pengalaman merasakan ketegangan dalam hidupnya. Cara individu dalam mensikapi kondisi stress pun berbedabeda antara individu yang satu dan individu yang lainnya. Hal itu tergantung dari pengalaman yang dimiliki oleh setiap individu, kepribadiannya, dan kondisi lingkungan hidupnya. Lebih lanjut, Acevedo dan Ekkekakis (2006:189) menyatakan bahwa stress dapat ditimbulkan, pertama: oleh karakteristik bawaan yang merupakan predisposisi keturunan dan keterbatasan pikologis individu. Kedua, dipengaruhi oleh faktor ling- kungan seperti kondisi dan situasi tempat tinggal serta pengalaman masa lalu individu. Dengan demikian munculnya stress dapat disebabkan oleh faktor dari dalam diri individu maupun faktor dari luar diri individu.

Stress, baik dalam dunia olahraga maupun dalam kehidupan masyarakat pada umumnya telah menjadi perhatian para pakar psikologi. Khusus dalam dunia olahraga stress menjadi kajian para pakar psikologi olahraga, tujuannya agar para atlet tidak terganggu penampilannya (performance) saat bertanding sehingga mampu menampilkan prestasi yang optimal. Dalam kehidupan masyarakat, stress menjadi kajian para pakar psikologi, dengan tujuan membantu individu agar terhindar dari stress sehingga dapat menikmati kehidupan ini dengan nyaman dan penuh bahagia. 
Stress muncul sejalan dengan peristiwa dan perjalanan kehidupan yang dilalui oleh individu dan terjadinya tidak dapat dihindari sepenuhnya. Pada umumnya, individu yang mengalami stress akan terganggu siklus kehidupannya dan merasakan ketidaknyamanan. Bahkan, stress yang berkelanjutan dapat membahayakan diri sendiri maupun orang lain sehingga masyarakat perlu memahami indikasi gejala stress, dampak stress pada diri individu, mengetahui penyebab stress, dan cara menguranginya. Tulisan berikut ini akan mencoba untuk menguraikan masalah stress dan cara menuranginya, agar para pembaca dapat mengenali dan mengatasinya sehingga dapat menjalani kehidupan dengan rasa nyaman dan bahagia.

\section{PENGERTIAN STRESS}

Dalam pengertian umum, stress adalah suatu tekanan atau sesuatu yang terasa menekan dalam diri individu. Sesuatu tersebut dapat terjadi disebabkan oleh ketidakseimbangan antara harapan dan kenyataan yang dinginkan oleh individu, baik keinginan yang bersifat jasmaniah maupun rohaniah. Menurut McGrath dalam Weinberg dan Gould (2003:81), stress didefinisikan sebagai "a substantial imbalance between demand (physical and/or psychological) and response capability, under conditions where failure to meet that demand has importance consequences". Artinya, stress akan muncul pada individu bila ada ketidakseimbangan atau kegagalan individu dalam memenuhi kebutuhannya baik yang bersifat jasmani maupun rohani.

Belum tentu semua individu yang mengalami ketidakseimbangan antara harapan dan kenyataan tersebut akan menjadikannya stress. Suatu stimulus yang sama akan direspons secara berlainan oleh individu yang berbeda. Artinya, tidak semua stimulus akan direspons menjadi stress oleh semua individu. Hal itu dikarenakan adanya perbedaan setiap individu dalam mensikapi setiap situasi, kemampuan meredam stimulus, dan pengalaman hidupnya. Selain itu, tingkat kepekaan (sensitivitas) dan daya toleransi individu terhadap stimulus yang dapat menimbulkan stress juga ikut berpengaruh. Pada dasarnya setiap individu memiliki ambang rangsang terhadap stress yang berbeda-beda dalam setiap situasi. Suatu stimulus pada saat tertentu akan menimbulkan stress, tetapi pada situasi yang berbeda tidak menimbulkan stress.

Bagiolahragawan maupun masyarakat nonolahragawan, keberadaan stress pada diri individu akan menimbulkan suatu kondisi yang tidak menguntungkan, sebab akan mengganggu kinerja dan produktivitas kerjanya. Namun, dalam dunia olahraga stress juga diperlukan menjelang pertandingan, meskipun dalam kadar yang ringan sebab keberadaan stress yang ringan diperlukan sebagai pemicu semangat individu dalam menghadapi suatu pertandingan. Dengan demikian, munculnya stress dalam kadar yang ringan akan membantu individu siaga (alert) dalam menghadapi pertandingan. Namun, jika stress yang muncul terlalu berat justru akan mengganggu penampilan olahragawan. Untuk itu, individu harus memahami kondisi stress dan mampu mengendalikannya agar dalam menjalani kehidupan dengan nyaman dan bahagia. 


\section{INDIKASI GEJALA STRESS}

Individu yang mengalami stress akan berperilaku lain dibandingkan dengan tujuannya yang tidak mengalami stress. Oleh karena itu, kondisi individu yang mengalami stress gejala-gejalanya dapat dilihat baik secara fisik maupun secara psikologis. Gejala secara fisik individu yang mengalami stress, antara lain ditandai oleh: gangguan jantung, tekanan darah tinggi, ketegangan pada otot, sakit kepala, telapak tangan dan atau kaki terasa dingin, pernapasan tersengal-sengal, kepala terasa pusing, perut terasa mual-mual, gangguan pada pencernaan, susah tidur, bagi wanita akan mengalami gangguan menstruasi, dan gangguan seksual (impotensi) (Waitz, Stromme, Railo, 1983: 52-71).

Gangguan jantung, bagi individu yang mengalami stress ada indikasi detak jantungnya lebih cepat (berdebardebar) daripada saat tidak mengalami stress. Ada juga individu yang merasakan dada sebelah kiri terasa nyeri (di daerah sekitar puting susu), meskipun hal tersebut tidak berlangsung terlalu lama, tetapi sesekali muncul lagi. Jika rasa berdebar atau nyerinya hilang tidak berarti bahwa stress yang dialami individu itu telah hilang. Untuk itu, diperlukan pencegahan agar stress tidak berlangsung lama, sebab semakin lama stress bersarang dalam diri individu dapat menjadi salah satu penyebab serangan jantung.

Tekanan darah tinggi (hipertensi) dapat diakibatkan oleh stress yang diderita individu, sebab reaksi yang muncul terhadap impuls stress adalah tekanan darahnya meningkat. Selain itu, umumnya individu yang mengalami stress sulit tidur, sehingga akan berdampak pada tekanan darahnya yang cenderung tinggi. Bukan rahasia lagi bagi individu yang memiliki hipertensi berpotensi untuk terserang stroke. Untuk itu, disarankan setiap individu harap rajin mengecek tekanan darahnya baik sistolik maupun diastoliknya, terutama bagi yang sudah berumur 40 tahun ke atas. Sistolik adalah indikasi tekanan darah yang dipompakan ke luar dari jantung, sedangkan diastolik adalah indikasi tekanan darah saat kembali ke bilik jantung.

Ketegangan pada otot dapat juga diakibatkan oleh stress yang diderita individu. Pada umumnya, ketegangan terjadi pada kelompok otot di daerah tengkuk, leher, bahu, dan rahang. Ketegangan otot di sekitar tengkuk akan mengganggu suplai darah ke otak, akibatnya kepala terasa nyeri karena kekurangan suplai darah. Jika kondisi seperti itu berlangsung lama maka akan membahayakankesehatan individu. Untuk itu, diperlukan relaksasi pada kelompok otot yang relatif mudah tegang akibat stress tersebut.

Sakit kepala dapat diakibatkan oleh stress yang diderita individu, hal itu berkaitan dengan penjelasan di atas. Dampak dari ketegangan kelompok otot leher dan daerah di sekitar kepala tersebut, jika berlangsung lama akan membahayakan kesehatan karena suplai darah ke otak menjadi terganggu. Untuk itu, jika ada indikasi sakit kepala yang diakibatkan karena terlalu banyak pikiran, maka selain segera periksakan ke dokter, dapat juga dilakukan masase 
untuk merelaksasikan kelompok otot yang tegang tersebut. Dengan masase akan membantu memperlancar peredaran darah ke seluruh tubuh, sehingga setiap organ tubuh tercukupi kebutuhan darahnya.

Telapak tangan dan kaki terasa dingin, juga dapat diakibatkan karena suplai darah ke sel-sel otot lengan dan tungkai berkurang. Oleh karena suplai aliran darah ke otot-otot tangan dan kaki berkurang maka mengakibatkan tangan dan kaki terasa dingin. Indikasi lain individu yang mengalami stress ditandai dengan keluar keringat dingin pada telapak tangan.

Pernapasan tersengal-sengal, dapat diakibatkan dari reaksi stress yang melanda individu. Di atas telah dikemukakan bahwa stress mengakibatkan detak jantung berdebar-debar, sehingga pernapasan menjadi tersengal-sengal. Pernapasan yang normal adalah berirama dalam dan panjang saat menghela napas. Untuk itu, individu yang mengalami stress harus mampu merasakan pernapasan baik pada saat menarik maupun mengeluarkan udara. Oleh karena itu, latihan pernapasan merupakan salah satu metode yang baik untuk terapi bagi individu yang mengalami stress.

Kepala terasa pusing dan perut terasa mual-mual, dapat diakibatkan oleh stress dan ketegangan fisik yang lama. Keterkaitannya dengan stress seperti telah dijelaskan di atas, di mana gangguan peredaran darah akan berpengaruh terhadap berbagai kondisi fisiologis dan kondisi psikologis individu.

Stress akan mempengaruhi fungsi dan kerja usus serta lambung. Kondisi tersebut akan berdampak pada sistem pencernaan dan buang air besar menjadi terasa sakit (sembelit). Contohnya individu yang suka marah-marah akan berdampak pada kontraksi lambung yang akhirnya dapat mengakibatkan iritasi lambung. Untuk itu, disarankan individu, terutama para guru atau dosen, jangan mudah marah agar tidak mudah terlanda oleh stress dalam hidup ini, meskipun stress tidak dapat dihindari sepenuhnya.

Susah tidur dan stress merupakan hubungan yang bersifat timbal balik. Artinya, susah tidur dapat diakibatkan karena stress dan stress dapat mengkibatkan susah tidur. Padahal tidur yang berkualitas merupakan proses yang penting guna mengistirahatkan (merecovery) kondisi fisik maupun psikis. Selain itu, pada saat individu tidur merupakan proses pembangunan selsel yang rusak akibat akitifitas fisik. Untuk itu, seyogyanya setiap individu dalam sehari semalam (24 jam) waktu tidurnya harus teratur dan minimal berlangsung selama $7-8$ jam.

Gangguan menstruasi bagi wanita dapat juga ditimbulkan oleh faktor stress, yaitu menstruasi menjadi tidak teratur, masa subur menjadi pendek bahkan menjadi tidak subur lagi. Meskipun belum ada data penelitian yang valid, ada kecenderungan wanita yang sering mengalami stress akan sulit untuk mendapatkan keturunan. Adapun keluhan para wanita yang mengalami stress pada saat menstruasi adalah timbul rasa nyeri, sakit perut, mual-mual, dan pusing.

Individu yang mengalami stress ada kecenderungan menurun libidonya. Ji- 
ka tingkat stress individu lebih berat cenderung akan mengalami impoten. Apalagi penyebab munculnya stress karena faktor perselingkuhan, maka pasangan suami istri tersebut hampir pasti tidak memiliki libido lagi di antara keduanya.

Gejala secara psikologis individu yang mengalami stress, antara lain ditandai oleh: perasaan selalu gugup dan cemas, peka dan mudah tersinggung, gelisah, kelelahan yang hebat, enggan melakukan kegiatan, kemampuan kerja dan penampilan menurun, perasaan takut, pemusatan diri yang berlebihan, hilangnya spontanitas, mengasingkan diri dari kelompok, dan pobia (Waitz, Stromme, Railo, 1983:41-50).

Perasaan selalu gugup dan cemas, merupakan indikasi individu yang mengalami stress saat menghadapi permasalahan. Jika individu selalu gugup setiap menghadapi masalah antara lain seperti saat akan ujian mid semester, ujian, menghadap pimpinan, di mana kondisi tersebut merupakan indikasi dari perasaan stress.

Individu yang mengalami stress perasaannya menjadi peka dan mudah tersinggung (sensitif). Setiap hal yang ada disekitarnya dirasakan selalu mengawasi individu yang mengalami stress. Pada hal kondisi lingkungan semua berjalan biasa dan tidak ada syak wasangka terhadap individu yang sedang stress tersebut. Kondisi seperti itu dapat menyebabkan individu yang mengalami stress selalu gelisah perasaannya, di mana gejala secara fisik diwujudkan dengan berjalan mondar-mandir tanpa tujuan yang jelas.
Penampilan yang tampak seperti orang yang kelelahan sekali merupakan indikasi stress. Meskipun tidak sehabis bekerja keras individu yang stress tampak seperti orang yang amat sangat kelelahan, sehingga enggan untuk melakukan berbagai kegiatan fisik. Selain itu, individu yang stress perilakunya menjadi lamban, kemampuan kerja dan penampilan juga menurun.

Individu yang mengalami stress merasakan ketakutan yang tidak beralasan. Seringkali perasaan takut itu dapat terbawa dalam mimpi-mimpi yang menyeramkan saat tidur sehingga saat bangun tidur mestinya individu merasa segar, tetapi karena mimpi-mimpi tersebut mengakibatkan saat bangun tidur menjadi terasa lelah.

Individu yang mengalami stress cenderung banyak merenung atau memusatkan diri yang berlebihan. Kondisi seperti ini akan diikuti oleh individu dengan perilaku mengasingkan diri dari kelompok atau lingkungannya. Oleh karena itu, jika tidak cepat diambil tindakan untuk terapi, individu tersebut cenderung akan cepat naik kelas dari stress menjadi depresi.

Individu yang mengalami stress akan kehilangan spontanitas dan keceriaan. Individu yang mengalami stress tampilan wajahnya selalu kusam, cemberut, dan tatapan matanya kosong, sehingga tidak dapat gembira menghadapi situasi lingkungan. Ada kecenderungan muncul perasaan takut, bersalah, dan merasa tidak bermanfaat bagi siapapun. 
DAMPAK STRESS PADA INDIVIDU

Pada umumnya, individu yang mengalami ketegangan akan mengalami kesulitan dalam memanajemen kehidupannya, sebab stress akan memunculkan kecemasan (anxiety) dan sistem syaraf menjadi kurang terkendali. Pusat syaraf otak akan mengaktifkan saraf simpatis, sehingga mendorong sekresi hormon adrenalin dan kortisol yang akhirnya akan memobilisir hormonhormon lainnya. Individu yang berada dalam kondisi stress, kondisi fisiologisnya akan mendorong pelepasan gula dari hati dan pemecahan lemak tubuh, dan bertambahnya kandungan lemak dalam darah (Waitz, Stromme, Railo, 1983:2). Kondisi tersebut akan mengakibatkan tekanan darah meningkat dan darah lebih banyak dialihkan dari sistem pencernaan ke dalam otot-otot, sehingga produksi asam lambung meningkat dan perut terasa kembung serta mual. Oleh karena itu, stress yang berkepanjangan akan berdampak pada depresi yang selanjutnya juga berdampak pada fungsi fisiologis manusia, di antaranya gagal ginjal dan stroke.

Pada dasarnya, penyakit disfungsi secara fisiologis itu diakibatkan oleh terganggunya kondisi psikologis seseorang. Sebagai contoh, perilaku agresif dan defensif individu dapat disebabkan oleh akumulasi stress yang tidak mampu dikenali dan dieliminir oleh individu. Selain itu, kondisi sosial ekonomi individu yang serba kekurangan dan lingkungan hidup (seperti di desa dan di kota besar) juga berpotensi melahirkan stress. Hal itulah salah satu faktor yang memunculkan berbagai kejahatan di kota-kota besar. Sebagai dampak da- ri kondisi masyarakat atau individu yang stress mudah memunculkan bentuk perilaku agresif karena berbagai faktor kesenjangan kondisi dan status masyarakat yang mencolok. Pada sisi lain, perilaku generasi muda di kotakota besar yang mengarungi hidup dengan mengkonsumsi miras dan narkoba merupakan bentuk defensif dari kondisi stress yang menimpa dirinya.

Secara garis besar dampak stress dapat menimpa pada kondisi fisik dan kondisi psikologis individu. Seperti telah dijelaskan pada indikasi gejala stress di atas. Berikut ini dampak stress terhadap fisik individu. 


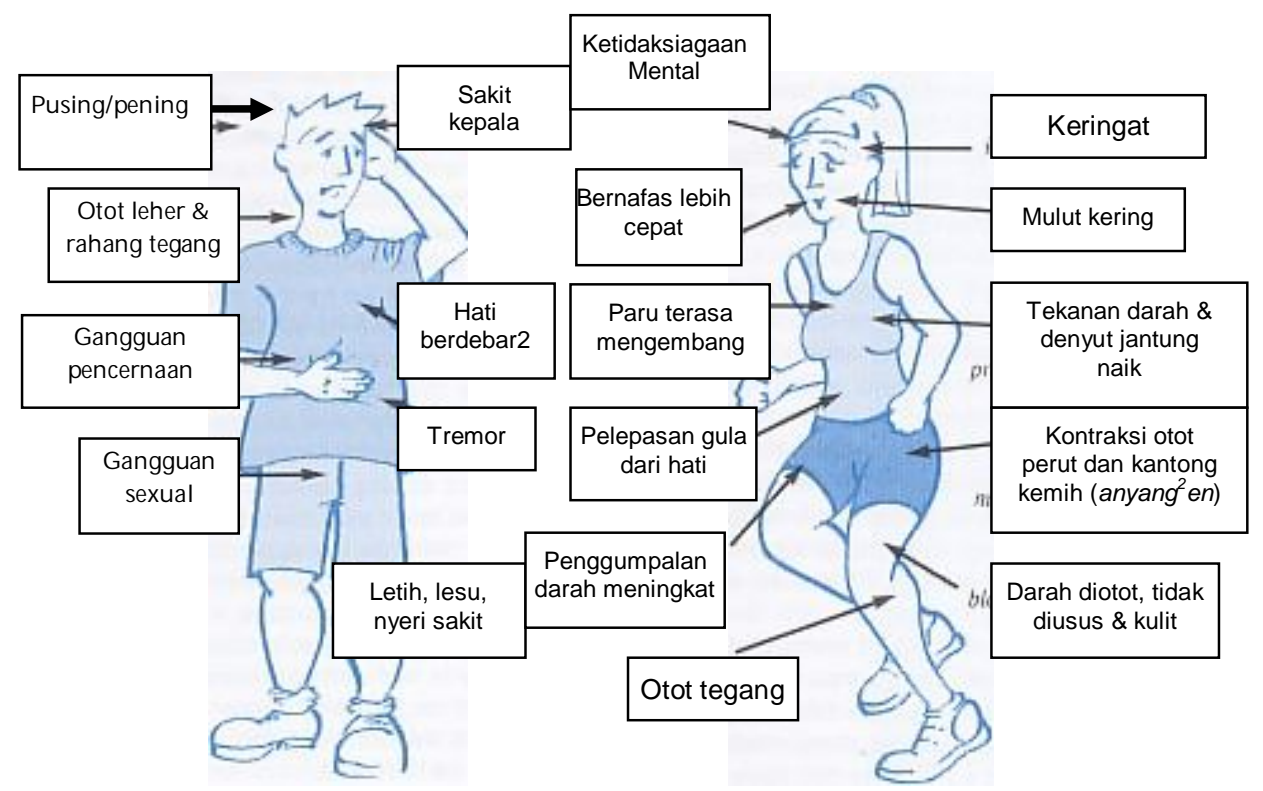

Lake (2004: 8-9)

\section{PENYEBAB STRESS}

Stress memang merupakan bagian dari kehidupan manusia, namun stress tidak akan datang dengan tiba-tiba tanpa adanya suatu penyebab. Artinya, stress muncul tentu ada penyebabnya, untuk itu individu harus mampu mencari penyebab stress agar dapat mengenali, mengurangi bahkan menghilangkan stress yang melanda dirinya. Oleh karena individu yang tidak mengalami stress akan merasakan hidupnya nyaman dan bahagia. Dengan demikian, stress harus dijauhkan dari kehidupan individu, agar dapat menjauhkan stress maka setiap individu harus mampu mengenali penyebabnya. Dengan mengetahui penyebabnya, selanjutnya akan mampu mengurangi dampak stress tersebut pada diri individu sehingga da- pat merasakan nikmatnya hidup di dunia ini.

Di atas telah disebutkan bahwa munculnya stress disebabkan oleh faktor yang berasal dari dalam diri individu dan faktor yang berasal dari luar diri individu. Adanya kesenjangan antara harapan dan kenyataan menimbulkan konflik dalam diri individu, sehingga berdampak pada munculnya stress. Berikut ini beberapa hal yang dapat menyebabkan muncul stress pada indivi$\mathrm{du}$, antara lain: perasaan cemas mengenai hasil yang dicapai, aktivitas yang tidak seimbang, tekanan dari diri sendiri, suatu kondisi ketidakpastian, perasaan cemas, perasaan bersalah, jiwa yang dahaga secara emosional, dan kondisi sosial ekonomi.

Perasaan cemas mengenai hasil yang dicapai akan menimbulkan stress. 
Sebagai contoh, jika seorang dosen terlalu banyak beban pekerjaan di kantor dan pekerjaan itu harus selesai dalam waktu yang bersamaan, kondisi seperti itu jelas akan menimbulkan stress. Oleh karena dosen juga manusia yang penuh dengan berbagai keterbatasan, maka diperlukan seorang pemimpin yang bijak dalam pembagian tugas kepada bawahannya agar tidak banyak menimbulkan stress.

Aktifitas yang tidak seimbang dapat sebagai pemicu munculnya stress, terutama aktifitas yang berlebihan, sehingga individu tidak memiliki waktu yang cukup untuk merecovery dirinya. Selain itu, kedekatan dengan keluarga atau orang yang dicintai akan berkurang akibat dari padatnya kegiatan yang dilakukan. Berbagi cerita (sharing) dengan orang-orang yang dicintai atau dengan keluarga merupakan sarana untuk berkeluh kesah yang dapat mengurangi beban kepenatan psikologis. Untuk itu, perlu jalinan hubungan komunikasi yang harmonis dalam rumah tangga agar terhindar dari potensi terserang oleh stress.

Tekanan dari diri sendiri dapat menimbulkan stress, terutama bagi individu yang selalu ingin tampil sempurna (perfectionist). Segala sesuatu yang tidak sesuai dengan keinginannya akan mendorong individu itu untuk menyempurnakannya, sementara pekerjaan yang diembannya cukup banyak sehingga menyita waktu yang banyakpula. Oleh karena itu, tipe orang yang perfectionist memiliki potensi yang lebih besar untuk mudah terserang stress dalam hidupnya.
Kondisi ketidakpastian juga akan menimbulkan stress, sebab ketidakpastian membuat individu menjadi tidak menentu. Sebagai contoh, seorang pria yang mendekati seorang gadis, di mana masih dalam taraf penjajagan dan belum ada tanda lampu hijau, maka si pria tersebut pada dasarnya sedang dalam kondisi stress yang disebabkan oleh perasaannya apakah berhasil atau gagal pendekatan yang dilakukan. Kondisi seperti itu akan menimbulkan stress meskipun dalam taraf yang masih ringan.

Perasaan cemas adalah suatu kondisi yang khawatir terhadap suatu masalah yang tidak jelas penyebabnya. Rasa cemas dapat juga diakibatkan oleh sifat individu yang memang pencemas (traits-anxiety). Perasaan khawatir merupakan pikiran yang negatif, pada hal pikiran negatif memunculkan perasaan negatif dan akhirnya mengakibatkan stress. Perasaan cemas mendorong munculnya stress pada individu. Selain itu, individu yang selalu merasa bersalah juga dapat mengakibatkan muncul stress karena apa saja yang dikerjakan tidak pernah benar.

Stress dapat muncul pada individu yang jiwanya merasa dahaga secara emosional. Menurut Abraham Maslow, kebutuhan manusia yang mendasar selain kebutuhan fisiologis dan biologis, juga memerlukan kebutuhan akan cinta kasih, kasih sayang, dihormati, dan dihargai oleh orang lain. Jika kebutuhan individu tersebut tidak terpenuhi, maka merasa menjadi manusia yang aneh, sehingga menimbulkan konflik dalam dirinya yang akhirnya muncul stress. Selain itu, jiwa yang dahaga secara spiritual juga dapat menyebabkan stress. 
Individu yang tidak mengenal dan tidak dekat dengan Tuhan pendiriannya labil dan mudah goyah. Individu yang menyalahkan Tuhan merupakan indikasi dari tidak dekatnya kepada Tuhannya.

Kondisi sosial ekonomi juga dapat menimbulkan stress. Orang mengalami stress akibat kondisi ekonomi yang serba kekurangan. Apalagi sebelumnya individu tersebut pernah memiliki status sosial ekonomi yang mapan, tetapi tiba-tiba terkena PHK akibatnya potensi munculnya stress akan lebih dominan. Oleh karena itu, rejeki, nasib, dan jodoh sudah di atur oleh Tuhan, manusia seharusnya tidak melampaui wewenang Tuhan. Manusia yang demikian itu adalah manusia yang arogan dan yang dapat memicu munculnya stress. Sifat sabar, tawakal dan menerima apa adanya dapat membantu mengurangi terjadinya stress.

\section{CARA MENGURANGI STRESS}

Untuk mengurangi stress yang muncul dalam diri setiap individu, yang pertama dan utama adalah mengetahui penyebab timbulnya stress. Dengan mengetahui penyebabnya, akan mempermudah dalam menentukan cara mengurangi stress yang muncul pada diri individu.

Beberapa cara untuk mengurangi stress antara lain melalui pola makan yang sehat dan bergisi, memelihara kebugaran jasmani, latihan pernapasan, latihan relaksasi, melakukan aktivitas yang menggembirakan, berlibur, menjalin hubungan yang harmonis, menghindari kebiasaan yang jelek, meren- canakan kegiatan harian secara rutin, memelihara tanaman dan binatang, meluangkan waktu untuk diri sendiri (keluarga), menghindari diri dalam kesendirian.

Pola makan yang sehat dan bergisi. Pada umumnya pola makan yang sehat adalah minimal makan 3 kali dalam sehari, dan menunya 4 sehat 5 sempurna. Untuk itu, yang perlu diperhatikan adalah jenis asupan makanan komposisinya harus seimbang antara karbohidrat, lemak, dan protein. Oleh karena asupan makanan juga dapat menyebabkan timbulnya stress pada individu, terutama jenis makanan yang mengandung lemak. Sebagai contoh kaum wanita yang banyak mengkonsumsi lemak cenderung akan mengalami kegemukan, dan kegemukan adalah momok bagi kaum wantia. Selain itu, orang yang mengalami stress akan terjadi pemecahan lemak tubuh sehingga menambah kandungan lemak dalam darah. Kondisi seperti itu akan mengganggu sistem peredaran darah dan mengakibatkan penyumbatan dalam pembuluh darah. Untuk itu, pola makan 4 sehat 5 sempurna perlu terus dilakukan, agar individu dapat terhindar dari stress. Budaya makan makanan yang bersifat instant harus segera dikikis guna menjamin asupan gisi yang sehat bagi jiwa dan raga.

Individu yang memiliki kebugaran jasmani baik akan terhindar dari stress, karena memiliki kemampuan ambang rangsang psikis yang tinggi terhadap stress. Sebab landasan yang kuat bagi kondisi psikologis individu adalah makanan yang sehat dan bergisi, waktu is- 
tirahat yang cukup, dan kebugaran jasmani yang baik (Loehr, 1993:149). Untuk itu, aktivitas jasmani yang dilakukan secara terprogram, terukur, teratur, dan rutin mampu mengurangi potensi serangan stress, selain itu juga mampu memelihara kebugaran jasmani individu. Dianjurkan individu non olahragawan untuk melakukan aktifitas fisik, antara lain seperti jogging, jalan, renang, bersepeda dengan intensitas ringan sampai sedang, dalam durasi waktu minimal 20 menit, frekuensinya 3 kali setiap minggu, akan membantu memelihara kebugaran jasmani.

Latihan pernapasan. Pernapasan yang baik adalah menarik napas secara perlahan dan dalam yaitu menggunakan diagphragma (Jawa: unjal ambegan) dan sesaat ditahan di perut, selanjutnya dikeluarkan secara perlahan pula. Cara bernapas seperti ini sangat membantu mereduksi stress. Sebagai contoh, jika individu mengalami jantung berdebardebar, lakukanlah bernapas secara perlahan dan dalam maka denyut jantung relatih akan lebih lambat. Permasalahan yang muncul sekarang, apakah pernapasan yang selama ini dilakukan oleh setiap individu sudah baik? Adapun caranya dengan merasakan pada saat menghirupmaupun mengeluarkan udara yang dilakukan secara perlahan dan dalam dengan memanfatkan diagphragma. Untuk itu, mulai dari sekarang perlu dilakukan latihan pernapasan yang baik dan benar agar semua individu terhindar dari stress yang berat.

Latihan relaksasi. Relaksasi sangat diperlukan baik secara fisik maupun psikis. Bagi olahragawan yang mengandalkan aktifitas fisik perlu melakukan masase secara rutin. Hal itu dimaksudkan untuk mengembalikan dan memperlancar simpul syaraf yang tidak dalam posisinya pada saat berolahraga. Menurut Lake (2004: 90) massage can be used as relaxation, reassurance, communication and fun. Untuk itu, tepat jika FIK UNY kini telah membuka klinik terapi fisik sebagai sarana mengaplikasikan ilmu dan sarana pengabdian pada masyarakat, guna membantu mewujudkan masyarakat yang jauh dari stress, sehingga tercipta warga masyarakat sehat jasmani dan rohani. Selain itu, relaksasi secara psikologis dapat dilakukan dengan cara mengkombinasikan latihan pernapasan dan relaksasi. Sebagai contoh bagi umat muslim pada waktu shalat tahajud atau setelah shalat subuh wajib melakukan dzikir atau wiridan yang dibarengi dengan merasakan dan melakukan cara bernapas yang baik dan benar. Insya Allah individu itu akan terhindar dari stress yang berat.

Melakukan aktivitas yang menggembirakan akan membantu individu terhindar dari perasaan stress. Sebab melalui aktivitas yang menggembirakan, individu yang memiliki masalah, sejenak akan melupakan permasalahannya. Oleh karena itu, akhir-akhir ini muncul terapi melalui tertawa yang sampai terbahak-bahak dan bahkan sampai menangis, yang tujuannya untuk mendorong munculnya hormon endorphin dari dalam diri individu itu sendiri. Cara ini dapat dikombinasikan dengan latihan kebugaran jasmani di atas, dengan aktivitas ringan sampai sedang minimal dalam waktu 20 menit juga dimaksudkan untuk mendorong munculnya hormon endorphin dari 
dalam diri individu itu sendiri. Dengan munculnya hormon endorphin tersebut akan berdampak pada individu merasakan riang dan gembira.

Berlibur atau rekreasi merupakan aktivitas yang bertujuan untuk melepaskan segala kelelahan (kepenatan) baik fisik maupun psikis dengan cara mengubah suasana yang menjadi rutinitas. Terutama bagi yang sudah berkeluarga berlibur sangat diperlukan guna menjalin hubungan yang harmonis antar anggota keluarga agar terjadi komunikasi yang harmonis pula. Selain itu, dengan perubahan suasana mampu menggairahkan kinerja individu yang mengalami kepenatan karena rutinitas pekerjaan atau beban pikiran yang terlalu berat.

Menjalin hubungan yang harmonis, hubungan dan komunikasi dengan pihak lain secara harmonis, terutama keluarga, akan membantu mereduksi potensi individu terserang stress. Sebagai contoh individu yang tidak diterima dengan baik dalam ligkungan keluarganya, akan menyebabkan stress sehingga perilakunya serba salah. Hal itu yang mengakibatkan individu tidak nyaman tinggal di rumah, jika kondisi seperti itu terus berkepanjangan berakibat broken home pada diri individu. Untuk itu, dalam keluarga harus diciptakan suasana dan komunikasi yang harmonis antar anggotanya agar terhindar dari stress. Selain itu, dengan tetangga atau rekan kerja jalinan yang harmonis terus digalakkan, agar dalam lingkungan atau satu ruang kerja tidak terjadi rasa permusuhan dan saling mencurigai satu dengan yang lainnya. Suasana lingkungan tempat tinggal atau tempat kerja yang tidak harmonis berpotensi melahirkan stress.

Menghindari kebiasaan yang jelek. Pada umumnya individu yang mengalami stress penyalurannya antara lain melalui merokok, makan secara berlebihan, minum minuman keras, dan mengkonsumsi narkoba. Sesaat mungkin kegiatan tersebut dapat menghilangkan stress, tetapi dalam jangka waktu yang lama dan berlebihan justru akan membahayakan terhadap kesehatan individu itu sendiri.

Merencanakan kegiatan harian secara rutin. Hidup adalah serangkaian rutinitas, namun manusia selalu melupakan rutinitas tersebut. Bahkan dalam menjalani hidup ini individu sering lupa dalam merencanakan kegiatan yang akan dijalani dalam satu hari ini. Sebagai contoh hari ini ada rapat atau seminar, tetapi individu tersebut jika lupa jadwal kegiatannya maka akan menimbulkan stress. Sebaliknya, jika individu mengetahui secara pasti jadwal kegiatan dari hari ke hari maka akan mengurangi resiko terkena stress.

Memelihara tanaman dan binatang dapat sebagai sarana untuk mengurangi beban stress pada individu. Dengan menanam dan merawat tanaman dapat sebagai hiburan dan pengalihan perhatian atau konsentrasi pada suatu permasalahan. Dengan merawat tanaman konsentrasi sesaat akan tercurahkan pada tanaman tersebut, sehingga beban stress dapat berkurang. Selain itu, memelihara binatang piaraan antara lain seperti kucing, anjing, burung, ikan dan sejenisnya merupakan hiburan yang 
mampu mengalihkan konsentrasi dari suatu permasalahan ke objek yang dirawat.

Meluangkan waktu untuk diri sendiri (keluarga). Seperti telah dijelaskan di atas dalam rekreasi atau meluangkan waktu bagi diri sendiri dan keluarga sangat diperlukan agar individu terhindar dari stress. Selain itu, kegiatan seperti memancing ikan dapat sebagai sarana mengurangi ketegangan pada individu yang mengalami stress.

Menghindari diri dalam kesendirian. Jika individu mengalami stress sebaiknya banyak bergaul dengan orang lain agar tidak dalam kesendirian, sebab jika dalam kesendirian individu itu akan semakin menikmati stressnya. Dengan semakin menikmati stress kondisinya akan semakin buruk dan membahayakan. Untuk itu, akan lebih baik individu yang mengalami stress mencari teman yang dapat diajak untuk mencurahkan isi hati (curhat), sehingga beban psikologis penyebab stress dapat dikurangi.

\section{PENUTUP}

Stress tidak pernah dapat dihindari oleh setiap individu selama dalam kehidupannya sehingga setiap individu harus mampu mengenali penyebab stress dan cara-cara menguranginya. Tujuannya agar individu dalam mengarungi kehidupannya tidak terlalu banyak terlanda stress, sehingga dapat menikmati kehidupan dengan layak, nyaman, dan bahagia. Untuk itu, perlu diciptakan lingkungan keluarga, lingkungan kerja, dan suasana yang harmonis serta kondusif agar warga masyarakat yang ada di lingkungan tersebut sejahtera lahir dan batin. Juga untuk selalu mendekatkan diri dengan Tuhan dan jangan lupa untuk selalu menyebut nama Tuhan di setiap waktu dan di setiap kesempatan. Insya Allah individu yang demikian itu akan tehindarkan dari stress. Semoga tulisan yang sederhana ini dapat membantu para pembaca terhindar dari stress yang berkepanjangan. Amin.

\section{UCAPAN TERIMA KASIH}

Terima kasih kami ucapkan kepada pengurus Jurnal Cakrawala Pendidikan, terutama Dewan Redaksi yang telah memberi masukan terhadap artikel ini.

\section{DAFTAR PUSTAKA}

Acevedo, Edmund O; Ekkekakis, Panteleimon (ed.). 2006. Psychobiology of Physical Activity. Champaign, Il.: Human Kinetics.

Cox, Richard H. 2002. Sport Psychology: Concepts and Applications, $4^{\text {th }}$ edition. New York: McGraw-Hill Co. Inc.

Lake, David. 2004. Stress: How to Cope with Pressure. Singapore: The Singapore Women's Weekly Health Series.

Loehr, J.1993. Toughness Training for Life. New York: Penguin Books Ltd.

Waitz, Grete; Stromme, Sigmund; Railo, Willi S. 1983. Conquer Stress with Grete Waitz, (terjemahan Sinta A. W). Bandung: Angkasa.

Weinberg, Robert S; Gould, Daniel. 2003. Foundations of Sport and Exercise Psychology, $3^{\text {rd }}$ edition. Champaign, Il.: Human Kinetics. 